\title{
Article
}

\section{Responsible volunteer tourism: tautology or oxymoron? A comment on Burrai and Hannam}

Sharpley, Richard Anthony john

Available at http://clok.uclan.ac.uk/19696/

Sharpley, Richard Anthony john ORCID: 0000-0002-2135-3206 (2017)

Responsible volunteer tourism: tautology or oxymoron? A comment on Burrai and Hannam. Journal of Policy Research in Tourism, Leisure and Events . pp. 1-5. ISSN 1940-7963

It is advisable to refer to the publisher's version if you intend to cite from the work. http://dx.doi.org/10.1080/19407963.2017.1362798

For more information about UCLan's research in this area go to http://www.uclan.ac.uk/researchgroups/ and search for <name of research Group>.

For information about Research generally at UCLan please go to http://www.uclan.ac.uk/research/

All outputs in CLoK are protected by Intellectual Property Rights law, including Copyright law. Copyright, IPR and Moral Rights for the works on this site are retained by the individual authors and/or other copyright owners. Terms and conditions for use of this material are defined in the policies page.

\section{CLoK}

Central Lancashire online Knowledge www.clok.uclan.ac.uk

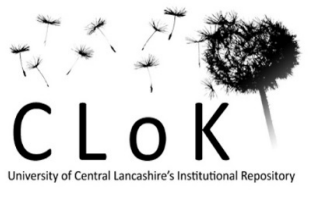




\section{Responsible volunteer tourism: tautology or oxymoron?}

\section{Introduction}

That so-called responsible volunteer tourism would be proposed as a new and, implicitly, morally superior form of volunteer tourism was entirely predictable. Though yet (perhaps thankfully) to enter the academic lexicon, responsible volunteer tourism or, more broadly, responsible volunteering, is a term increasingly employed to refer to a 'truly fulfilling and impactful voluntouring experience' (Plummer, 2015). In other words, it refers to an allegedly alternative approach to the volunteer tourism phenomenon that seeks to optimise the benefits to both the volunteer and host community whilst avoiding its recognised negative consequences (Guttentag, 2009; Palacios, 2010). And as such, the emergence of responsible volunteer tourism reflects that of the concept of responsible tourism more generally. Initially considered a necessary, though controversial, alternative to mass tourism development (Harrison and Husbands 1996; Hayward, 1988; Wheeller, 1991), responsible tourism has more recently been broadly conceptualised (again, controversially) as a means of minimizing tourism's negative consequences whilst enhancing both the well-being of host communities and the tourist experience (Goodwin, 2011).

This emphasis on 'responsible' inevitably suggests that, in some cases, volunteer tourism may be 'irresponsible’; that is, it may result in limited or unintended outcomes in terms of the volunteer's experience or the benefits accruing to the host community. And this is often the case. Many examples of such 'irresponsible' volunteer tourism are evident in the literature, from experiences that reinforce rather than challenge cultural stereotyping (Raymond \& Hall, 2008; Simpson, 2004) or serve to emphasise inequality (Lyons, Hanley, Wearing \& Neil, 2012; Sin, 2012) to more extreme consequences, such as the purposeful creation of 'orphanages' to exploit volunteer tourists (and children) for profit (see, for example, Farley, 2015). At the same time, others have noted more generally that, as an increasingly popular and potentially valuable sector of the international tourism market, volunteer tourism is vulnerable to over-commercialisation with the profit motive sometimes, but not always, undermining the more positive social and environmental credentials of volunteering projects (Tomazos \& Cooper, 2012). Hence, there exists an evident logic behind the ambition to connect potential volunteer tourists - at least, those with stronger altruistic motives described by Callanan and Thomas (2005: 197) as 'intermediate' to 'deep’ volunteer tourists - with more 'responsible' volunteer tourism organisations which are committed to 
bringing net developmental benefits to host communities (see, for example, responsiblevolunteering.co.uk).

Yet, aside from the well-rehearsed academic debates surrounding the phenomenon of volunteer tourism, comprehensively reviewed by Wearing and McGehee (2013), the question remains: is it appropriate to preface ‘volunteer tourism' with the word 'responsible'? In addressing this question, Elisa Burrai and Kevin Hannam critique the concept of responsibility as applied to volunteer tourism through broadly highlighting its inherent inequalities and the need to challenge private sector / market led initiatives by enhancing the role or responsibility of the state. Here, I adopt a different approach, both exploring the relevance of 'responsibility' to and challenging concept of volunteer tourism itself. That is, on the one hand, it may be argued that the term responsible volunteer tourism is tautological; that is, volunteering may generally be thought of as being altruistic and ethically sound - in short, it is, in principle, an intrinsically responsible form of behavior. On the other hand, responsible volunteer tourism (and, indeed, volunteer tourism more generally) might be considered a contradiction in terms, combining as it does a socially 'good' activity (volunteering) with the modern, primarily consumptive and ego-centric social institution that is tourism. This, in turn, would suggest that, contrary to Butcher and Smith's (2010: 28) argument that it is an 'appropriate term', the validity of concept of volunteer tourism itself (responsible or otherwise) demands reconsideration.

As a starting point, it is quite evident but, in the present context, still necessary to emphasise that the practice of volunteering, particularly overseas volunteering, significantly predates the concept of volunteer tourism. According to Gillette (1999), the first modern international voluntary movement, Service Civil International, was founded in France in the early 1920s while in the UK, Voluntary Service Overseas (VSO) first sent just 16 volunteers overseas in 1958, since when more than 48,000 volunteers have worked on international developmental projects (see vsointernational.org). Similarly, the Peace Corps was established as an agency within the US Department of State in 1961, providing volunteering opportunities for more than 180,000 Americans over the ensuing decades. Conversely, it was only following the publication of Wearing's (2001) text, Volunteer Tourism: Experiences that Make a Difference, that volunteer tourism became the focus of increasing academic attention during a period when, not coincidentally, the popularity of the 'gap year' and participation in volunteering as part of overseas travel experiences (and the number of organisations selling such experiences) grew rapidly. In other words, the concept of volunteer tourism emerged only when an already established activity - overseas volunteering - was in 
effect appropriated and commercialised by a variety of organisations and, for many participants, transformed into a tourism experience. In so doing, the proponents of volunteer tourism have established a distinction, both conceptually and in practice, between 'traditional' overseas volunteering and contemporary tourism experiences that, to a lesser or greater extent, involve a period of volunteering.

Equally, it should also be noted that volunteering (both domestic and international) has long been the focus of academic attention, particularly since the early 1990s, both in general and as a form of 'serious leisure' (Parker, 1992; Stebbins, 1996). Much of the research explores issues such as intrinsic motives for engaging in volunteering, demographic and contextual factors that influence the nature and extent of such engagement and its benefits to the volunteer (see Wilson, 2000; also Meier \& Stutzer, 2006) - all of which have subsequently been explored (or, rather, the research has been repeated) within the volunteer tourism literature. For example, as Wearing and McGehee (2013) observe, an ongoing theme in the volunteer tourism literature is the 'altruism vs. self-interest' debate. According to Wilson (2000: 215), however, volunteering is 'any activity in which time is given freely to benefit another person, group, organization'; and interestingly, he goes on to state that this definition 'does not preclude volunteers from benefitting from their work.' Putting it another way, volunteering can be seen simply as a productive activity or 'an activity that produces goods and services at below market rate' (Wilson 2000: 216).

Two points emerge from this. First, contrary to what many claim (for example, Bussell \& Forbes, 2002), volunteering may be undertaken for either altruistic or selfish reasons, or even a combination of the two; hence, 'responsible volunteering' may sometimes, but not always, be a tautology and, consequently, debates surrounding the altruism or selfinterest of volunteer tourists, though academically stimulating, are arguably of less relevance than those surrounding the outputs, or the product, of their volunteering. Yet, as has been recognized (Wearing \& McGehee, 2013), only limited attention has been paid to this in the literature, a surprising omission given arguments with regards to the role of volunteering in international development (Devereux, 2008)

Second, (responsible) volunteer tourism is a confusing and, perhaps, contradictory term. As already noted, the coining of the term and subsequent burgeoning academic attention paid to it over the last fifteen years not only clearly delineates volunteer tourism as a niche sector of the international market (Callanan \& Thomas, 2005), but also implies that it is distinctive from the long-established overseas volunteering sector. This, in turn, both highlights an issue raised by others, that volunteer tourism is an oxymoronic concept 
(Butcher \& Smith, 2010), and perhaps more significantly, emphasises the touristic element of the activity. In other words, overseas volunteering and volunteer tourism share, of course, the common characteristic of international travel. The former, however, is generally regarded as a specific, organised and typically longer-term activity engaging individuals with the skills relevant to the developmental needs of the host community. For example, Palms Australia, a long-established (1956) volunteering organization, states that:

An international volunteer seeks to achieve just and sustainable development by giving themselves and their skills to achieving development outcomes identified by a local community and consistent with the development objectives of the host country. (Palms Australia, 2017)

That is, the focus is on the benefits accruing the the host community. The latter, conversely, though often defined sufficiently broadly to include all forms of international volunteering, is concerned primarily with shorter-term volunteering as part or all of a holiday (Wearing, 2001). The emphasis is primarily on the benefits accruing to the volunteer as a tourist and, indeed, not only does much of the research address the volunteer tourist experience, but studies have revealed that, for many, the principle motives for engaging in volunteer tourism is the travel experience (see, for example, Daldeniz \& Hampton, 2010). In other words, volunteer tourism is, essentially, a tourism experience.

For the purposes of this essay, this leads to the conclusion that if the word 'responsible' is to be attached volunteering, then it is only relevant to what has been referred to here as overseas volunteering, participants in which are unlikely to considered themselves as tourists. Conversely, there is, perhaps, a need to re-assess the validity of the term 'volunteer tourism', endowing as it does the consumption of a particular tourism experience with an aura of altruism, citizenship or, indeed, 'responsibility' that may not exist.

\section{References}

Bussell, H. and Forbes, D. (2002) Understanding the volunteer market: The what, where, who and why of volunteering. International Journal of Non-profit and Volunteer Sector Marketing, 7(3), 244-257. 
Butcher, J. and Smith, P. (2010) ‘Making a difference’: Volunteer tourism and development. Tourism Recreation Research, 35(1), 27-36.

Callanan, M. and Thomas, S. (2005) Volunteer tourism: deconstructing volunteer activities within a dynamic environment. In M. Novelli (Ed.), Niche Tourism: Contemporary Issues, Trends and Cases (pp. 183-200). Oxford: Butterworth-Heinemann.

Daldeniz, B. \& Hampton, M. (2010) Charity-based Voluntourism versus 'Lifestyle Voluntourism: Evidence from Nicaragua and Malaysia. Working paper 211, University of Kent: Kent Business School.

Devereux, P. (2008) International volunteering for development and sustainability: Outdated paternalism or a radical response to globlaisation? Development in Practice 18(3), 357-370.

Farley, J. (2015) Potential Short-term International Volunteers’ Perceptions of Children's Residential Care in Cambodia. Phnom Penh, Cambodia: Friends International.

Gillette, A. (1999) A (very) short history of volunteering. Available at: http://volunteering.ge/upload/pdf/b7e88087fbf77747309c21116496a0da.pdf (Accessed 1 March 2017)

Goodwin, H. (2011) Taking Responsibility for Tourism. Oxford: Goodfellow Publishers Ltd. Guttentag, D. (2009) The possible negative impacts of volunteer tourism. International Journal of Tourism Research, 11(6), 537-551.

Harrison, L. and Husbands, W. (1996) Practising Responsible Tourism: International Case Studies in Tourism Planning, Policy and Development. Chichester: John Wiley \& Sons.

Haywood, K. (1988) Responsible and responsive tourism planning in the community. Tourism Management 9(2), 105-118.

Lyons, K., Hanley, J., Wearing, S. and Neil, J. (2012) Gap year volunteer tourism: Myths of global citizenship? Annals of Tourism Research, 39(1), 361-378.

Meier, S. and Stutzer, A. (2008) Is volunteering rewarding in itself? Economica, 75, 39-59.

Palacios, C. (2010) Volunteer tourism, development and education in a postcolonial world: Conceiving global connections beyond aid. Journal of Sustainable Tourism, 18(7), 861-878.

Palms Australia (2017) An international volunteer ethos. Available at: www.palms.org.au/papers/an-international-volunteer-ethos (Accessed 2 March 2017) 
Parker, S. (1992) Volunteering as serious leisure. Journal of Applied Recreation Research, 17(1), 1-11.

Plummer, A. (2015) Responsible voluntourism: Doing good abroad. The Changer. Available at: http://thechanger.org/community/responsible-voluntourism-doing-good-abroad

Raymond, E. and Hall, C.M. (2008) The development of cross-cultural (mis) understanding through volunteer tourism. Journal of Sustainable Tourism, 16(5), 530-543.

Simpson, K. (2004) 'Doing development': The gap year, volunteer-tourists and a popular practice of development. Journal of International Development,16 (5), 681-692.

Sin, H. (2010) Who are we responsible to? Locals' tales of volunteer tourism. Geoforum, 41(6), 983-992.

Stebbins, R (1996) Volunteering: A serious leisure perspective. Nonprofit and Voluntary Sector Quarterly, 25(2), 211-224.

Tomazos, K. and Cooper, W. (2012) Volunteer tourism: At the crossroads of commercialisation and service? Current Issues in Tourism, 15(5), 405-423.

Wearing, S. (2001) Volunteer Tourism: Experiences that Make a Difference. Wallingford: CABI.

Wearing, S. and McGehee, N. (2013) Volunteer tourism: A review. Tourism Management, 38, 120-130.

Wheeller, B. (1991) Tourism's troubled times: responsible tourism is not the answer. Tourism Management 12(2), 91-96.

Wilson, J. (2000) Volunteering. Annual Review of Sociology, 26, 215-240. 